\title{
Strength Developing in Clay-Andesite Brick
}

\author{
Víctor Julio García1,2, Alonso R. Zúñiga-Suárez², Carmen Omaira Márquez ${ }^{1,3}$, Juan G. Pérez², \\ Francisco Fernández-Martínez ${ }^{2,4}$, Francisco Hernández-Olivares ${ }^{2,4}$ \\ ${ }^{1}$ Universidad Nacional de Chimborazo, Riobamba, Ecuador \\ ${ }^{2}$ Universidad Técnica Particular de Loja, Loja, Ecuador \\ ${ }^{3}$ Universidad de Los Andes, Mérida, Venezuela \\ ${ }^{4}$ Universidad Politécnica de Madrid, Madrid, España \\ Email: vgarcia375@gmail.com
}

Received 27 June 2016; accepted 8 August 2016; published 11 August 2016

Copyright (C) 2016 by authors and Scientific Research Publishing Inc.

This work is licensed under the Creative Commons Attribution International License (CC BY). http://creativecommons.org/licenses/by/4.0/

(c) (i) Open Access

\section{Abstract}

The objective of this work was to develop a more and better understanding of the strength developing in clay-andesite fired brick. The purpose was to improve the quality of the clay bricks that are handmade in the southern region of Ecuador to make them suitable for more widespread use in the local construction industry. To achieve our goal, we first physically, chemically, and mechanically characterized the "clayey" and "sandy" materials used in the fabrication of handmade bricks in the region. Second, the optimal mixture (OM): the optimal proportion between the amounts of "clayey" and "sandy" material was sought. Third, clay bricks were prepared using the OM, baked at $950^{\circ} \mathrm{C}$, and characterized. In addition, bricks produced by regional artisans were characterized, and the results were compared with the results obtained for the bricks prepared using the $0 \mathrm{M}$. Our data reveal that the optimal mixture is 50\% "clayey" material and $\mathbf{5 0 \%}$ "sandy" material and that with this mixture, an average improvement in brick quality of $300 \%$ can be achieved; thus, the use of the OM makes it possible to expand the use of these bricks in the local construction industry and enables an environmentally friendly production process by reducing the intensive exploitation of regional clay deposits. This improvement is achieved by virtue of the anorthite enrichment that occurs in the solid solution, which results from the evolution of andesine. The anorthite contributes to the formation of a stronger matrix among the different grains of the material. Conditions are favorable for this enrichment process to occur when "sandy" materials with high contents of andesite, which is common in Ecuadorian soils, are used.

\section{Keywords}

Anorthite, Andesine, Andesite Component, Fired Bricks, Brazilian Test 


\section{Introduction}

Solid clay bricks are one of the oldest and most extensively used construction materials in human civilization. Clay bricks are formed through a simple manufacturing process (mixing, kneading, drying, and baking) and are an affordable product that is created using non-renewable resources, such as clay, which exists in abundance in diverse regions of the planet. Clay bricks offer solidity, durability, and compactness, among other potentially beneficial physical, mechanical, and thermal properties. However, clay brick technology has evolved very little throughout history, and efforts to improve its technological performance have received little attention. However, due to their low production costs and wide range of properties, clay bricks offer remarkable potential for technological development, although there is little fundamental knowledge available regarding the relationship among the composition, microstructure, and mechanical performance of such bricks [1]. For this reason, there is considerable interest in using technology to develop a new type of clay brick with improved performance in response to the technological challenges posed by the modern construction industry. However, the production of clay bricks has a high environmental impact in terms of the consumption of non-renewable resources (materials), energy, and water as well as the emission of greenhouse gases and the generation of waste, among other aspects [2]-[4].

The materials used in the clay brick industry are dispersed throughout the earth's surface and have their natural origins in complex geological processes that occurred during the formation of the earth's crust. The possibility of using these materials in the manufacture of clay bricks depends primarily on the geological and geochemical conditions in which the materials are formed, as well as on their mineralogical composition. The environmental impact due to the consumption of non-renewable resources is related to the availability of these clayey materials and to the exploitation of areas that must remain available for the conservation of biodiversity. Thus, the intensive exploitation of clay deposits poses a threat to environmental sustainability and also threatens the development of a sustainable construction industry. The mitigation of the environmental effects of clay brick production and the technological development of optimized clay bricks begins with the formulation of an OM, considering the compositions of both the "clayey" material and the available "sandy" material. The dominant component in an OM is quartz, but the most important ingredients are hydrated silicates or clay minerals, which endow the mixture with viscosity and plasticity once it is hydrated. Other ingredients include carbonates, iron oxides, and other minerals and their mixtures, which are used as fluidifiers or degreasers, among other purposes. The mineral compositions of these clayey minerals vary greatly. The amounts and compositions of these minerals directly influence the molding and drying of a brick before it is placed in the oven as well as its behavior during baking and the color and quality of the finished product.

However, the most suitable proportion of "clayey" and "sandy" materials depends, to a large extent, on the nature of the available materials. In addition, we must consider that the requirements for environmental preservation are continuously increasing [2]. Therefore, the optimization of the ratio of "clayey" material to "sandy" material represents an effective and important means of mitigating the environmental impact [5]. At the Andes mountain range, "sandy" material is found in surface deposits that usually have good amount of andesite. Actually, andesite most commonly denotes fine-grained and typically consist essentially of andesine (a plagioclase feldspar). Crystal of andesine lies in a finer groundmass, usually crystalline, but sometime glassy. Andesine consists of $70 \%$ to $50 \%$ albite and $30 \%$ to $50 \%$ anorthite. Andesine can decompose into anorthite and albite, as occurs in the regional model of thermal metamorphism [6] [7]. However, studies of the formation of anorthite and their effects on the increase in strength during sintering of clay based material are rare in the literature [8].

The objective of this work was to develop a more and better understanding of the strength developing in clay-andesite fired brick. The purpose was to improve the quality of the clay bricks that are handmade in the southern region of Ecuador to make them suitable for more widespread use in the local construction industry.

To achieve our goal, we first physically, chemically, and mechanically characterized the “clayey” and "sandy" materials used in the handmade production of bricks in the region. Second, the optimal proportion between the amounts of "clayey" and "sandy" materials was sought and determined. Third, clay bricks were prepared using the $\mathrm{OM}$ and sintered at $950^{\circ} \mathrm{C}$, and these bricks were then characterized. In addition, bricks produced by seven major artisanal producers from the region (with production capacities greater than 10,000 units) were characterized, and the results were compared with the results obtained for the bricks prepared using the OM. 


\section{Materials and Methods}

\subsection{Characterization of Raw Materials ("Clayey" and "Sandy" Materials)}

a) Granulometric analysis was performed using number 20, 40, 60, 100 and 200 mesh sieves to determine the particle size distribution [9].

b) The geotechnical properties of the prepared pastes were then determined. The plastic limit (PL) was determined using the 3-mm-thread method, and the liquid limit (LL) was determined using a Casagrande device [10]. The plasticity index (PI) was calculated based on the arithmetic difference between the LL and the PL. For brick preparation, the mixture was moistened to five percentage points above its LL.

c) The raw material samples were subjected to differential scanning calorimetric-thermo gravimetric analysis (DSC-TGA) using an SDT Q600 device (manufactured by the Thermal Analysis Company) equipped with a platinum-platinum/rhodium thermocouple. The analysis was performed between room temperature and $1000^{\circ} \mathrm{C}$ at a heating rate of $20^{\circ} \mathrm{C} / \mathrm{min}$ and under an oxygen flow. To achieve better peak resolution, a small amount of each sample was used (approx. $46 \mathrm{mg}$ ) and rapid heating was applied.

d) Chemical analysis (oxide percentage (wt \%)) of the samples was performed using X-ray fluorescence (XRF) spectroscopy (S1 TURBO ${ }^{\mathrm{SD}}$ handheld XRF analyzer, Bruker). For this analysis, the samples were mechanically ground in a planetary mill and reduced to powder in an agate mortar.

e) The crystalline phases were analyzed via the powder method using an X-ray diffractometer (D8 Advance, Bruker) equipped with a copper anode $\left(\lambda=1.5418 \times 10^{-10} \mathrm{~m}\right.$ ) and a linear detector (LYNXEYE compound silicon strip detector, Bruker). The diffractograms were collected in a range of 5 to 70 degrees using a step size of 0.02 degrees and a measurement time of 2 seconds per step. The diffractogram analysis was performed through a comparison with the Joint Committee on Power Diffraction Standards spectra using the DIFFRAC.SUITE EVA software from Bruker.

f) The porosity, density, amount of water absorbed, and dimensional variation of the samples were determined as follows.

The shrinkage of each sample after being dried (DS) in an oven was determined using Equation (1):

$$
\text { DS } \%=\frac{L_{1}-L_{2}}{L_{1}} \times 100 \% \text {. }
$$

In Equation (1), $L_{1}$ represents the length of the specimen after drying under ambient conditions, before being placed in the oven. The shrinkage of each sample after being baked and sintered in the oven (FS) was determined using Equation (2):

$$
\text { FS } \%=\frac{L_{2}-L_{3}}{L_{2}} \times 100 \% .
$$

In Equation (2), $L_{2}$ represents the length of the specimen after drying in the oven, before being placed in the baking oven. $L_{3}$ represents the length of the specimen after being baked or sintered in the oven. The total shrinkage (TS) was calculated as follows:

$$
\mathrm{TS}=\mathrm{FS}+\mathrm{DS}
$$

The density and porosity were determined using the gravimetric method based on Archimedes' principle. The specimens were saturated with water for $24 \mathrm{~h}$ and were then weighed while immersed in water $\left(W_{1}\right)$ and in air after the surface water had dried $\left(W_{2}\right)$. Subsequently, the samples were oven-dried for $6 \mathrm{~h}$ at a temperature of $105^{\circ} \mathrm{C}$ to completely remove the water, after which the dry specimens were weighed $\left(W_{3}\right)$.

The amount of water absorbed (WA) was determined using Equation (4), following the American Society for Testing and Materials (ASTM) standard [11]. This amount corresponds to the relative amount (by weight percent) of WA by the specimen while immersed under the prescribed conditions with respect to the weight of the dry specimen:

$$
W A(\%)=\frac{W_{2}-W_{3}}{W_{3}} \times 100 \% .
$$

The fraction of open pores $\left(f_{0}\right)$, or the apparent porosity [12], was calculated using Equation (5): 


$$
f_{\mathrm{o}}=\frac{W_{2}-W_{3}}{W_{2}-W_{1}} \times 100 \%=\left(1-\frac{\rho_{b}}{\rho_{S}}\right) \times 100 \% .
$$

The density of the solid phase $\left(\rho_{s}\right)$ and the apparent density $\left(\rho_{b}\right)$ were calculated using the ratios given in Equation (6) below [13]:

$$
\rho_{\mathrm{s}}=\frac{W_{3}}{W_{3}-W_{1}} \times \rho_{w} ; \quad \rho_{\mathrm{b}}=\frac{W_{3}}{W_{2}-W_{1}} \times \rho_{w} .
$$

In Equation (6), $\rho_{w}=997.04 \mathrm{~kg} / \mathrm{m}^{3}$ is the density of water at $25^{\circ} \mathrm{C}$. The percentage of mass lost during baking and sintering was estimated using the following Equation:

$$
L O S=\frac{W_{4}-W_{3}}{W_{3}} \times 100 \% .
$$

In Equation (7), $W_{4}$ represents the weight of the dry specimen before being placed in the oven for baking and sintering.

g) The indirect tensile (IT) test (the Brazilian test) was performed on the baked and sintered disks at various temperatures. In this test, the disk is vertically compressed to indirectly generate a tensile stress in the horizontal direction. The maximum value of the applied load $\left(P_{\max }\right)$ is recorded when the failure of the disk occurs, and the indirect tensile strength $\left(\sigma_{\mathrm{IT}}\right)$ is calculated using Equation (8):

$$
\sigma_{\text {IT }}=\frac{2 P_{\max }}{\pi D l} .
$$

In Equation (8), $D$ represents the disk diameter, and $l$ represents its thickness. The IT test offers several advantages with respect to other methods. The test configuration is simple, and cylindrical or disk-shape specimens are used. A large sample volume can therefore be tested using this method, and it is not sensitive to surface defects [14].

h) The compressive strength of the bricks was determined following the ASTM standard [11], and the tests were performed in quintuplicate. For these tests, a universal testing machine was used (Versa Tester, Soil Test Inc., USA), and the compressive strength was determined by dividing the maximum applied load by the area of the brick face subjected to the load.

i) For the drying of the bricks and disks, the samples were left in the molds for $12 \mathrm{~h}$ and were then dried for $72 \mathrm{~h}$ under ambient conditions. Subsequently, they were oven-dried at $105^{\circ} \mathrm{C}$ for $24 \mathrm{~h}$. The samples were heated at a heating rate of $0.08^{\circ} \mathrm{C} / \mathrm{min}$ from room temperature to $60^{\circ} \mathrm{C}$ (approx. $8 \mathrm{~h}$ ) and were then maintained at that temperature for $3 \mathrm{~h}$; subsequently, the temperature was further raised at the same heating rate to $105^{\circ} \mathrm{C}$, at which they remained for $4 \mathrm{~h}$. The oven was disconnected, and the samples were allowed to cool inside the oven until they reached room temperature.

j) In the baking and sintering of the bricks and disks, the disks were baked and sintered at $500^{\circ} \mathrm{C}, 700^{\circ} \mathrm{C}$, and $950^{\circ} \mathrm{C}$, whereas the bricks were baked only at $950^{\circ} \mathrm{C}$. The baking and sintering were performed in an electric oven at a heating rate of $1.66^{\circ} \mathrm{C} / \mathrm{min}$ until the final temperature was reached, and this temperature was then maintained for $3 \mathrm{~h}$. Finally, the samples were allowed to cool freely via natural convection until they reached room temperature.

\subsection{Experimental Design}

The raw "clayey" and "sandy" materials used to produce the handmade bricks were obtained from the natural deposits at "La Vega (LVG)" and "Indiucho (IND)", respectively. Both deposits are located in the Catamayo Canton of Loja Province in Ecuador. The LVG deposit is located at a southern latitude of $4^{\circ} 00^{\prime} 39.7^{\prime \prime}$ and a western longitude of $79^{\circ} 22^{\prime} 43.51 "$, and its geomorphological structure belongs to the Gonzanamá Formation. The IND deposit is located at a southern latitude of $4^{\circ} 01^{\prime} 47.4^{\prime \prime}$ and a western longitude of $79^{\circ} 21^{\prime} 54.5^{\prime \prime}$, between the Sacapalca and Loma Blanca Formations. The Gonzanamá Formation dates from the Paleocene and rests discordantly on the Sacapalca Formation; it predominantly consists of sedimentary volcanic rocks such as dark-brown clays, gray lutites, tuffaceous sandstones, and tuffs. It is believed that this formation has a thickness of approximately 1000 meters. The Sacapalca Formation dates from the Paleogene and exhibits a lithology of andesitic 
lavas and pyroclastic rocks. The lavas are resistant to erosion and are located in the highest parts of the Catamayo Basin, whereas the pyroclastic rocks correspond to andesitic tuffs, agglomerate tuffs, and subordinate agglomerates. The lavas are brown or gray andesitic porphyry, with a high content of mafic minerals, including enstatite, hornblende, and augite. The Loma Blanca Formation dates from the Oligocene-Miocene and rests discordantly on the Gonzanamá Formation; it essentially consists of an agglomerate basal portion followed by a sequence of stratified medium-grain white tuffs, whose layers have an inclination angle of approximately 124 degrees in the SE direction. The rocks of this formation are wrapped in a silty matrix containing clasts of mainly variegated tuffs with sizes ranging from millimeters to centimeters. The formation is superimposed with a sequence of agglomerate tuffs, tuffs, and pyroclastic flows, whose deposition environment is of the continental type [15] [16].

The samples were sieved (sieve \#18) to remove the inert components of the material, thereby obtaining grains of less than $1 \mathrm{~mm}$. No specialized treatment, such as those reported by Kornilov and Luzin [17], was used for the activation of the clays. We characterize the clayey (from LVG deposit) and sandy materials (from IND deposit) by doing granulometric analysis, XRF, differential thermo gravimetric analysis, X-ray diffraction and the geotechnical properties of the 90/10 mixture. The optimization of the mixture and its characterization were performed following the procedure outlined in Figure 1.

To determine the OM, a simplex-reticular method was used, and mixtures were prepared with the following ratios of clayey/sandy materials, expressed in terms of the total weight percentage of the mixture: 30 - 70, 40 60, 50 - 50, 60 - 40, and 70 - 30. The materials were carefully aerated and manually mixed. Water was added to each mixture until a uniform consistency was achieved. Then, the pastes were allowed to rest for $24 \mathrm{~h}$ in sealed bags (maturation process) to achieve the maximum possible plasticity. Subsequently, portions of each paste were placed in circular molds of $75 \mathrm{~mm}$ in diameter and $20 \mathrm{~mm}$ in thickness to obtain disk-shaped samples. Three replicates were prepared for each formulation, yielding a total of fifteen samples. To achieve soft extrusion, a weight of $500 \mathrm{~g}$ was placed on each sample for $60 \mathrm{~min}$ while it was in the mold. Subsequently, the fifteen samples were dried at $105^{\circ} \mathrm{C}$ and then baked and sintered at $950^{\circ} \mathrm{C}$. The disks were subjected to the IT test at a loading speed of $0.010 \mathrm{~mm} / \mathrm{min}$. To determine the $\mathrm{OM}$, we defined the optimization factor $\left(f_{\text {opt }}\right)$ in a manner similar to the structural efficiency factor defined in [18]. Thus, we defined the optimization factor as the ratio of the maximum stress supported by the sample under indirect tension $\left(\sigma_{\mathrm{IT}}\right)$, expressed in MPa, to the sample weight ( $p$ ), expressed in kg. Thus,
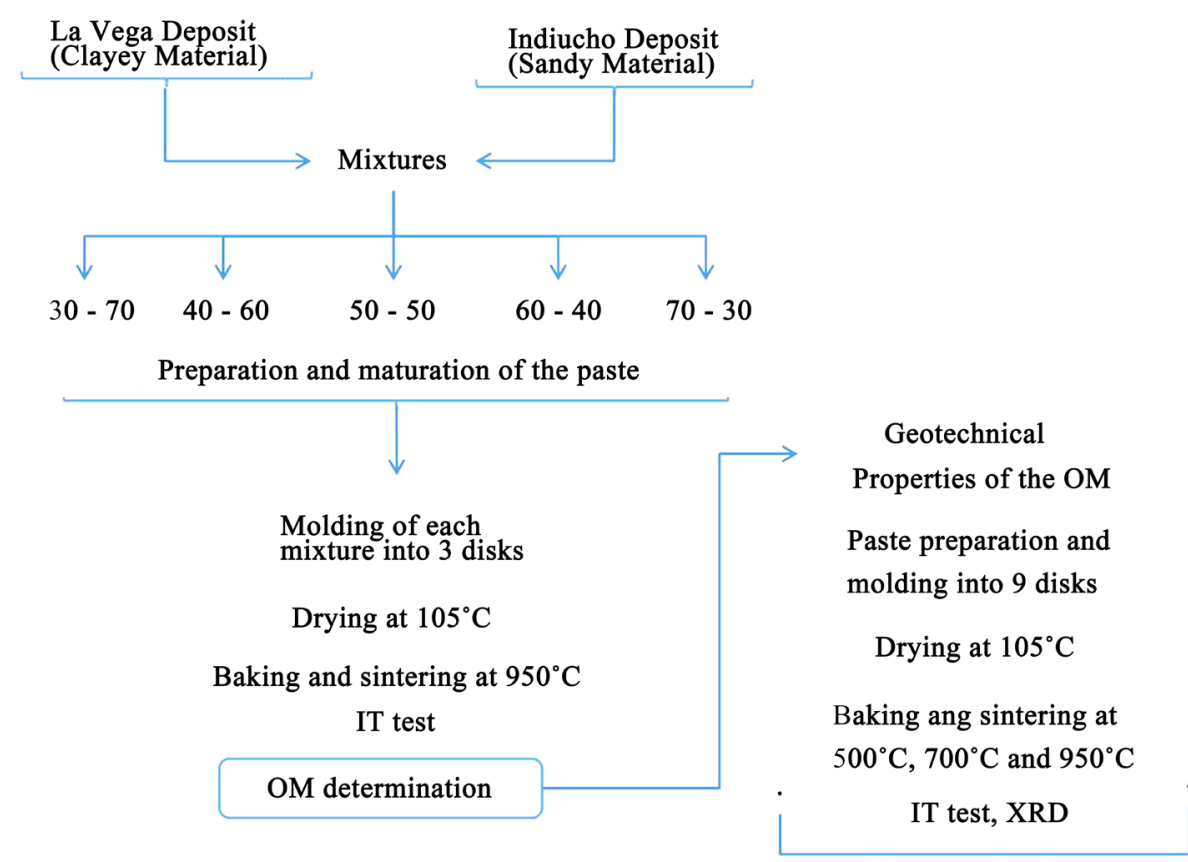

Figure 1. Methodology implemented to determine and characterize the OM. IT test represents the indirect tensile test. 


$$
\begin{gathered}
f_{\mathrm{opt}} \equiv \frac{\sigma_{\mathrm{IT}}}{p}, \\
f_{\mathrm{opt}} \equiv \frac{2}{\pi D l} \times \frac{P_{\mathrm{max}}}{p} .
\end{gathered}
$$

In Equation (10), $D$ represent de diameter of the sample and $l$ is its thickness. The OM was defined as the composition of the disk that exhibited the highest value of the optimization factor. Once the OM was identified, additional paste was prepared using that formulation. The geotechnical properties of the paste were determined, and it was used to prepare nine disk-shaped samples following the procedure described above. Once the samples were dried, they were divided into three sets of three. One set was baked and sintered up to a temperature of $500^{\circ} \mathrm{C}$, the second was sintered at a temperature of $700^{\circ} \mathrm{C}$, and the third was sintered at $950^{\circ} \mathrm{C}$. The sintered disks were subjected to the IT test, and their chemical compositions were analyzed via X-ray diffraction.

Subsequently, sufficient paste to make five bricks was prepared by hydrating the OM paste to five percentage points above its LL. The paste was allowed to rest and then used to fill wooden molds of $270 \times 140 \times 80 \mathrm{~mm}$. A weight of approx. $3 \mathrm{~kg}$ was placed on each mold to achieve soft molding or extrusion. The bricks were allowed to dry following the protocol described in section (2.1.i). Afterward, the bricks were baked and sintered following the method presented in section (2.1.j). Then, following the protocol described in section (2.1.f), conventional characterization (dimensional variation, water adsorption, density, and porosity) of the bricks prepared in the laboratory and the brick produced by the regional artisans was performed. Subsequently, the bricks were subjected to the direct compression test in accordance with the methodology defined in section (2.1.h).

The results obtained in the tests of the bricks prepared in the laboratory were compared with those obtained in the tests performed on the handmade bricks from the regional producers.

\section{Results and Discussion}

\subsection{Chemical Composition and X-Ray Diffraction}

The chemical compositions of the LVG and IND samples are shown in Table 1. The analysis results are expressed as the percentages of oxides present, where the main chemical elements are $\mathrm{Si}, \mathrm{Al}, \mathrm{Fe}$, and $\mathrm{Ca}$. These oxide contents can be summarized as $56 \%$ to $61 \% \mathrm{SiO}_{2}, 19 \%$ to $24 \% \mathrm{Al}_{2} \mathrm{O}_{3}, 3 \%$ to $8 \% \mathrm{CaO}$, $8 \%$ to $9 \% \mathrm{Fe}_{2} \mathrm{O}_{3}+$ $\mathrm{TiO}_{2}$, and $4 \%$ to $8 \% \mathrm{RO}+\mathrm{R}_{2} \mathrm{O}$. The diffractograms of the LVG and IND samples are presented in Figure 2, in which several of the most intense peaks are marked. A semi-quantitative analysis of the diffractograms shown in Figure 2 reveals that the LVG sample contained a mixture of illite (8\%); muscovite-2 M (4\%); kaolinite (18.3\%); several plagioclases, such as sodium anorthite (3.6\%), albite (5\%), and andesine (7.56\%); and quartz (41.76\%). Meanwhile, in the IND diffractogram, the plagioclases sodium anorthite (3.22\%), albite (5.81\%), and andesine (62.70\%), as well as diopside (9.97\%) and quartz (15.78\%), predominate.

Table 1. Chemical compositions of the LVG and IND samples determined via XRF.

\begin{tabular}{ccc}
\hline & LVG (\%) & IND (\%) \\
$\mathrm{SiO}_{2}$ & 56.52 & 60.02 \\
$\mathrm{Al}_{2} \mathbf{O}_{3}$ & 23.08 & 19.28 \\
$\mathbf{C a O}$ & 3.51 & 7.64 \\
$\mathrm{Fe}_{2} \mathbf{O}_{3}$ & 8.07 & 7.33 \\
$\mathbf{M g O}$ & 4.59 & 3.24 \\
$\mathbf{K}_{2} \mathbf{O}$ & 2.42 & 0.82 \\
$\mathbf{M n O}$ & 0.17 & 0.20 \\
$\mathrm{TiO}_{2}$ & 0.75 & 0.77 \\
$\mathrm{Sb}_{2} \mathbf{O}_{3}$ & 0.24 & 0.25 \\
\hline
\end{tabular}




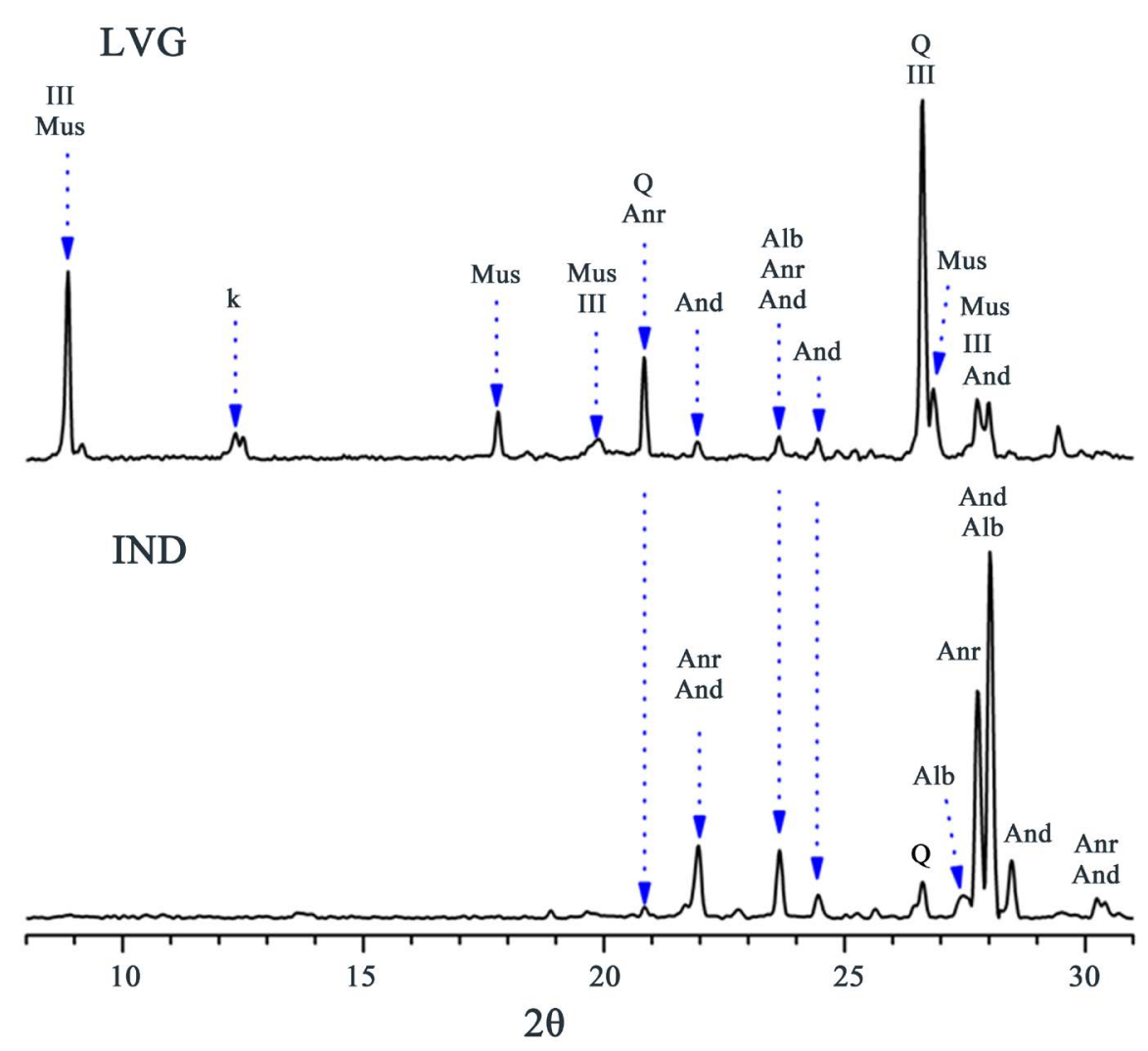

Figure 2. Diffractograms of the LVG and IND samples. Illite (Ill); muscovite-2M (Mus); kaolinite (k); anorthite (Anr), albite (Alb), and andesine (And); and quartz (Q).

Adequate baking and/or sintering of a mixture used for brick fabrication requires knowledge of the thermal behaviors that the raw material can exhibit when subjected to a heating program. Such knowledge allows the changes in volume, phase, and crystallization, among others, that can occur during the heating process to be understood and anticipated. In addition, the most suitable baking temperature prior to vitrification can be determined. The thermal phenomena exhibited by a material as its temperature is increased, until it decomposes, depend to a large extent on the material's purity, its chemical composition, the nature of the bonds between its constituents (binding energy between atoms and/or molecules), and its surface properties. For example, clays with fine grains tend to decompose more readily than clays with coarse grains [19].

\subsection{Thermo Gravimetric Analysis}

The temperatures at which the different thermal phenomena occur can be studied using thermal analysis methods such as differential thermal analysis, thermo gravimetric analysis (TGA), and differential scanning calorimetry (DSC). However, for samples that are a mixture of diverse materials, such as the materials used to prepare clay bricks, the interpretation of the data is complicated by the simultaneous occurrence of thermal phenomena of different origins. To facilitate the interpretation of the thermograms, we can use the first (D1) and second (D2) derivatives of the thermogram with respect to temperature to more clearly or explicitly visualize the occurrence of thermal events. The D2-DSC curve represents the changes in the heat flow rate of the sample during a range of diverse thermal processes, such as endo-and exothermic decomposition. The D2-DSC curve provides complementary information to facilitate better evaluation of the simultaneously occurring thermal processes recorded in the TGA and DSC thermograms. The thermograms of the LVG and IND samples are presented in Figure 3.

In the DSC curve shown in Figure 3(a), it can be observed that during the initial heating period, the sample released water in an endothermic reaction up to a temperature of approximately $120^{\circ} \mathrm{C}$. In this process, the sample lost $4.58 \%$ of its mass, probably as a result of the removal of hygroscopic water from the clayey material 

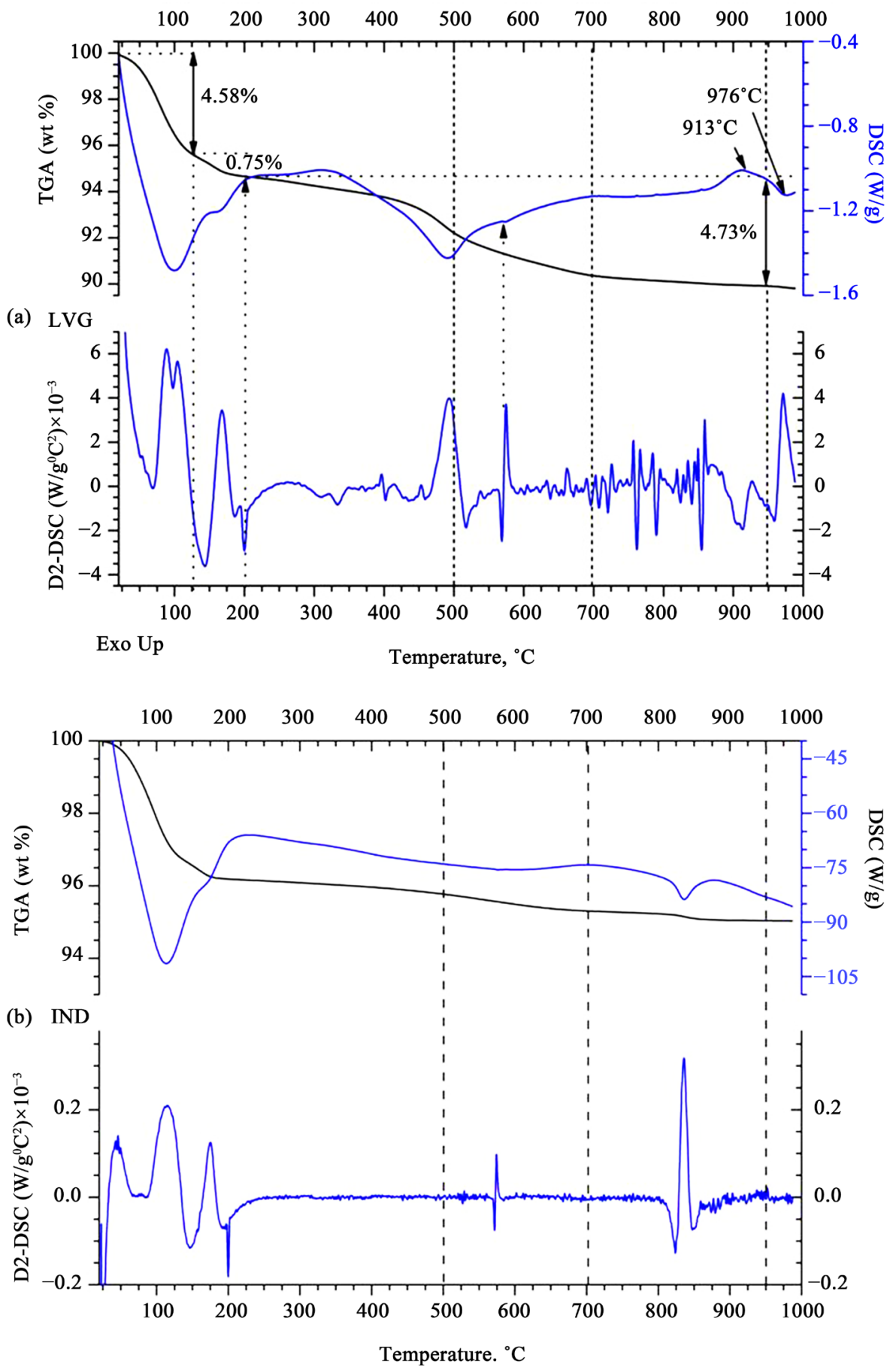

Figure 3. TGA, DSC, and D2-DSC thermograms of the LVG (a) and IND (b) samples. The dotted lines represent the final sintering temperatures.

(see the TGA curve in Figure 3(a)). The wet mass exhibited a dimensional change during drying at temperatures in the range of 0 to $150^{\circ} \mathrm{C}$ takes because of the loss of water from its pores [20]. Above $120^{\circ} \mathrm{C}$ and up to approximately $200^{\circ} \mathrm{C}$, a turning point appears in the DSC thermogram of Figure 3(a), probably related to the removal of hygroscopic water from the illite and other minerals, which caused the sample to lose approximately $0.75 \%$ of its weight. In the literature, it has been reported that the effect associated with kaolin in this temperature range is very small compared with that associated with illite [21]. At $200^{\circ} \mathrm{C}$, a sharp endothermic peak is 
evident, probably due to the thermal desorption of weakly absorbed (physisorbed) water adhered to the particle surfaces through a van der Waals-type attraction. Such water is adsorbed at active sites associated with defects in the structure and is typically observed to be present in amounts directly proportional to the number of particles. In the range from $200^{\circ} \mathrm{C}$ to $500^{\circ} \mathrm{C}$, the oxidation of organic matter typically occurs, and the loss of energy due to the loss of organic mass associated with the clay particles is relatively low [21]. In fact, the combustion of organic matter depends on the size of its constituent particles and on their distribution in the sample, which gives rise to small but wide peaks during heating. In the range of $300^{\circ} \mathrm{C}$ to $350^{\circ} \mathrm{C}$, a maximum can be observed in the DSC curve in Figure 3(a), probably related to loss of water from the hydrated iron oxide [22]. In fact, a maximum can be observed in the D2-DSC curve in Figure 3(a) in the range of $304^{\circ} \mathrm{C}-315^{\circ} \mathrm{C}$, where the thermal energy flow remains constant over a small temperature range before it begins to decrease once again [21]. In the D2-DSC curve of Figure 3(a), between $380^{\circ} \mathrm{C}$ and $480^{\circ} \mathrm{C}$, several events can be observed that are not visible in the DSC curve because they overlap with the organic matter decomposition; these events correspond to the dehydroxylation of the clay. Dehydroxylation is a thermally activated reaction and depends on many factors, of which time and temperature are the most important variables. This dehydroxylation is a process in which water molecules form and is removed from the structure of the clayey minerals, following the reaction

$\mathrm{OH}^{-}+\mathrm{OH}^{-} \rightarrow \mathrm{H}_{2} \mathrm{O}+\mathrm{O}^{2-}$ [23]. The dehydroxylation activation energies of the minerals decrease in the following order: illite, muscovite, montmorillonite, and kaolinite [24]; this process is not clearly observed in other minerals, so it is not discernible in the curve in Figure 3(a).

Kaolinite is characterized by a prominent endothermic effect in the range of $450^{\circ} \mathrm{C}$ to $570^{\circ} \mathrm{C}$, followed by the destruction of the mineral crystalline network and the formation of metakaolin accompanied by the release of water, following the reaction described in Equation (11) [25]-[27]. The formation of the water molecules generates voids in the crystalline network, and when sufficient voids have formed, the structure deforms, producing metakaolin:

$$
\mathrm{Al}_{2} \mathrm{Si}_{2} \mathrm{O}_{5}(\mathrm{OH})_{4} \rightarrow \mathrm{Al}_{2} \mathrm{Si}_{2} \mathrm{O}_{7}+2 \mathrm{H}_{2} \mathrm{O} .
$$

The maximum of this endothermic event depends on the heating rate, occurring at $443^{\circ} \mathrm{C}$ when the heating rate is $1^{\circ} \mathrm{C} / \mathrm{min}$ and at $527^{\circ} \mathrm{C}$ when the heating rate is $40^{\circ} \mathrm{C} / \mathrm{min}$ [28]. The recrystallization of kaolinite occurs between $950^{\circ} \mathrm{C}$ and $1000^{\circ} \mathrm{C}$, accompanied by a considerable release of energy, which should be observed in the thermogram as a sharp exothermic peak [20] [29].

The loss of water from the illite results in an initial endothermic peak between $100^{\circ} \mathrm{C}$ and $150^{\circ} \mathrm{C}$ due to dehydration, followed by a second endothermic peak near $460^{\circ} \mathrm{C}-470^{\circ} \mathrm{C}$ due to dehydroxylation and a third peak near $900^{\circ} \mathrm{C}$ that is associated with the final dehydroxylation stage [20] [30]. However, Gualtieri and Ferrari reported the existence of at least two endothermic peaks in the range from $600^{\circ} \mathrm{C}$ to $700^{\circ} \mathrm{C}$ in the dehydroxylation process of illite [24] [29]. In its final state, the onset of the dehydroxylation process occurs before the decomposition of the original silicate structure. The thermal decomposition of illite begins at $800^{\circ} \mathrm{C}$, and as the temperature increases, hematite is formed at the expense of silicate [31]. At $910^{\circ} \mathrm{C}$, the illite recrystallizes in an exothermic process [29].

Muscovite-2M1 exhibits a significant phase change at approximately $800^{\circ} \mathrm{C}$, which is attributed in the literature to a dehydroxylation process. The dehydroxylation of muscovite-2M1 occurs in the temperature range between $700^{\circ} \mathrm{C}$ and $1000^{\circ} \mathrm{C}$ and is accompanied by the nucleation and growth of the dehydroxylated phase at high temperatures [32]. Two thermal processes have been associated with the dehydroxylation of muscovite-2M1: one at $475^{\circ} \mathrm{C}$ and another at $750^{\circ} \mathrm{C}$ [33]. The process involves the condensation of two hydroxyl groups to form a water molecule via the following reaction:

$$
\mathrm{KAl}_{2}\left(\mathrm{Si}_{3} \mathrm{Al}\right) \mathrm{O}_{10}(\mathrm{OH})_{2} \rightarrow \mathrm{H}_{2} \mathrm{O}+\mathrm{KAl}_{2}\left(\mathrm{Si}_{3} \mathrm{Al}\right) \mathrm{O}_{11} .
$$

Anorthite (Anr), with the formula $\mathrm{CaAl}_{2} \mathrm{Si}_{2} \mathrm{O}_{8}$, and albite (Alb), with the formula $\mathrm{NaAlSi}_{3} \mathrm{O}_{8}$, lie at the extremes of a continuous series of reactions in a solid solution of plagioclases, as described by Bowen. The intermediate members of the series are homogeneous mixtures of the products at the extremes and include albite, which consists of $100 \%$ to $90 \%$ Alb and $0 \%$ to $10 \%$ Anr; andesine, which consists of $70 \%$ to $50 \%$ Alb and $30 \%$ to $50 \%$ Anr; labradorite, which consists of $50 \%$ to $30 \%$ Alb and 50\% to $70 \%$ Anr; and anorthite, which consists of $10 \%$ to $0 \%$ Alb and $90 \%$ to $100 \%$ Anr. This series of plagioclases forms a solid homogenous solution at high and low temperatures, and it arises through the complete substitution of sodium and silicon with calcium and aluminum. 
Pure anorthite $\left(\mathrm{Anr}_{100}\right)$ exhibits a reversible structural phase transition (a primitive structure of space group Pí to a body-centered structure of space group Ií ) at approximately $237^{\circ} \mathrm{C}$ [34].

Albite exists in two crystalline forms: a completely ordered form that is stable at low temperatures, called "low albite" or simply albite, and a disordered form that is stable at high temperatures, called "high albite". The transformation from albite to "high albite" occurs in the temperature range of $490^{\circ} \mathrm{C}$ to $670^{\circ} \mathrm{C}$ [35].

Andesine can decompose into anorthite and albite, as occurs in the regional model of thermal metamorphism. Its homogeneous superstructure with periodic boundaries and non-periodic anti phase boundaries (APB) is locally distorted because of the energy accumulated along the closely spaced two-dimensional defects. Thus, the APB recombine in one region of the crystal to form anorthite $\left(\mathrm{Anr}_{95}\right)$, and in another region of the same crystal, the structure is transformed into albite $\left(\mathrm{Anr}_{<5}\right)$, without generating a superstructure [6] [7].

At $573^{\circ} \mathrm{C}$, alpha trigonal quartz transforms into beta hexagonal quartz. This transformation can be explicitly observed in the D2-DSC curve in Figure 3(a). The quartz content can be determined from the change in enthalpy, which, for pure quartz, is on the order of $7.5 \mathrm{~J} / \mathrm{s}$ [33]. It can be expected that at $870^{\circ} \mathrm{C}$, the beta quartz must irreversibly transform into beta tridymite, undergoing a significant change in volume (approximately 14.4\%), but the kinetics of this reaction is very slow, and it never occurs below $1250^{\circ} \mathrm{C}$. A gradual decomposition of quartz can also be expected in the range of $800^{\circ} \mathrm{C}-1100^{\circ} \mathrm{C}$, with a significant decrease in its content at $1100^{\circ} \mathrm{C}$ [21]. However, when impurities are present, the beta quartz can instead irreversibly transform into alpha cristobalite at $1050^{\circ} \mathrm{C}$ or $1250^{\circ} \mathrm{C}$ [36].

All peaks related to the release of carbonate in the D2-DSC curve of Figure 3(a) must appear as narrow peaks in the temperature range of $640^{\circ} \mathrm{C}$ to $740^{\circ} \mathrm{C}$ [21]. Several processes occur in the range of $700^{\circ} \mathrm{C}$ to $900^{\circ} \mathrm{C}$ that are more visible in the D2-DSC curve in Figure 3(a) and are associated with the decomposition of the clays and of the calcite. Calcite can decompose over a wide temperature range, from $650^{\circ} \mathrm{C}$ (decarbonation of polycrystalline calcite) to approximately $850^{\circ} \mathrm{C}$, at which the decomposition of monocrystalline calcite occurs. At $810^{\circ} \mathrm{C}$, the decarbonation of carbonates with particle sizes similar to those of the clays occurs [29].

The thermograms collected for the IND samples are shown in Figure 3(b), in which thermal events similar to those observed for the LVG sample are evident, particularly those in the temperature range between $120^{\circ} \mathrm{C}$ and $200^{\circ} \mathrm{C}$. The endothermic peak at $573^{\circ} \mathrm{C}$ is related to the transformation of alpha quartz into beta quartz. However, in contrast to the thermograms of the LVG sample, Figure 3(b) exhibits a prominent endothermic peak at approximately $835^{\circ} \mathrm{C}$, which can be attributed to sodium anorthite or K-feldspar [4].

Finally, in Figure 3(a), it can be observed that at $976^{\circ} \mathrm{C}$, vitrification of the clay occurred in the LVG sample, turning it into a fragile material. Therefore, we concluded that the most suitable baking temperature for clays of this type must lie between these last two temperatures, and thus, we selected the samples that were baked at $950^{\circ} \mathrm{C}$ for further examination.

\subsection{Indirect Tensile Test and Structural Evolution}

The IT test results for specimens with different proportions of IND and LVG materials baked at $950^{\circ} \mathrm{C}$ are summarized in Table 2. In the presence of a tensile stress, the disks prepared using the various mixtures behaved similarly to somewhat fragile materials such as concrete and rocks. The tensile strength of such materials is very low compared with the compressive strength and is frequently ignored. The tensile strength depends primarily on the strength of the mineral grains and on the matrix that holds them together. In addition, there is also some dependence on the chemical composition, the presence of inclusions, and the quality and dimensions of the pores. For this reason, the strength of such a material strongly depends on the strength of its weakest

Table 2. Results of tests performed to optimize the proportions of LVG and IND materials in the mixture using specimens sintered at $950^{\circ} \mathrm{C}$.

\begin{tabular}{ccccccccccc}
\hline LVG (\%) & IND (\%) & $P(\mathrm{~g})$ & $D(\mathrm{~cm})$ & $l(\mathrm{~cm})$ & $P_{\max }(\mathrm{KN})$ & $\sigma_{\mathrm{IT}}(\mathrm{MPa})$ & $f_{\text {opt }}(\mathrm{MPa} / \mathrm{kg})$ & LOS (\%) & DS (\%) & FS (\%) \\
\hline 30 & 70 & 118.81 & 6.94 & 1.70 & 0.56 & 0.40 & 3.24 & 5.27 & 0.30 & 10.71 \\
40 & 60 & 147.95 & 6.85 & 2.24 & 1.33 & 0.55 & 3.75 & 5.75 & 0.29 & 2.36 \\
50 & 50 & 117.29 & 6.79 & 1.84 & 1.42 & 0.73 & 6.20 & 6.33 & 0.24 & 1.52 \\
60 & 40 & 137.66 & 6.71 & 2.21 & 1.55 & 0.67 & 4.90 & 6.90 & 0.43 & 2.98 \\
70 & 30 & 139.64 & 6.66 & 2.28 & 1.68 & 0.71 & 5.12 & 7.61 & 0.49 & 4.63 \\
\hline
\end{tabular}


regions; the homogenous clayey material used as one of the raw materials, with its low content of impurities, provided a high tensile strength [37].

Figure 4(a) shows the values of the optimization factor defined in Equation (10) for each of the tested samples. The mixture with a ratio of 50 - 50 exhibited the highest optimization factor $(6.20 \mathrm{MPa} / \mathrm{kg})$ and also the lowest dimensional variations after drying $(0.24 \%)$ and after baking and sintering (1.52\%). Based on these results, we defined the OM as a mixture containing $50 \%$ of LVG material and 50\% of IND material, or, in other words, with a proportion of 50 - 50. Figure 4(b) shows the diffractograms corresponding to three samples with

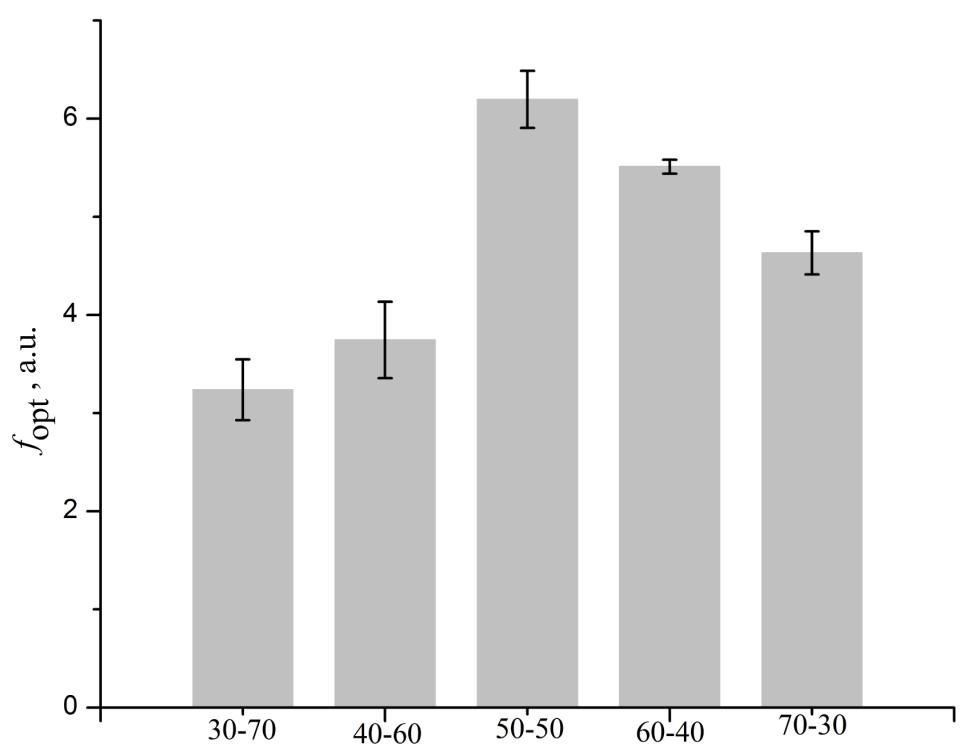

(a)

Mixture (LVG - IND), \%
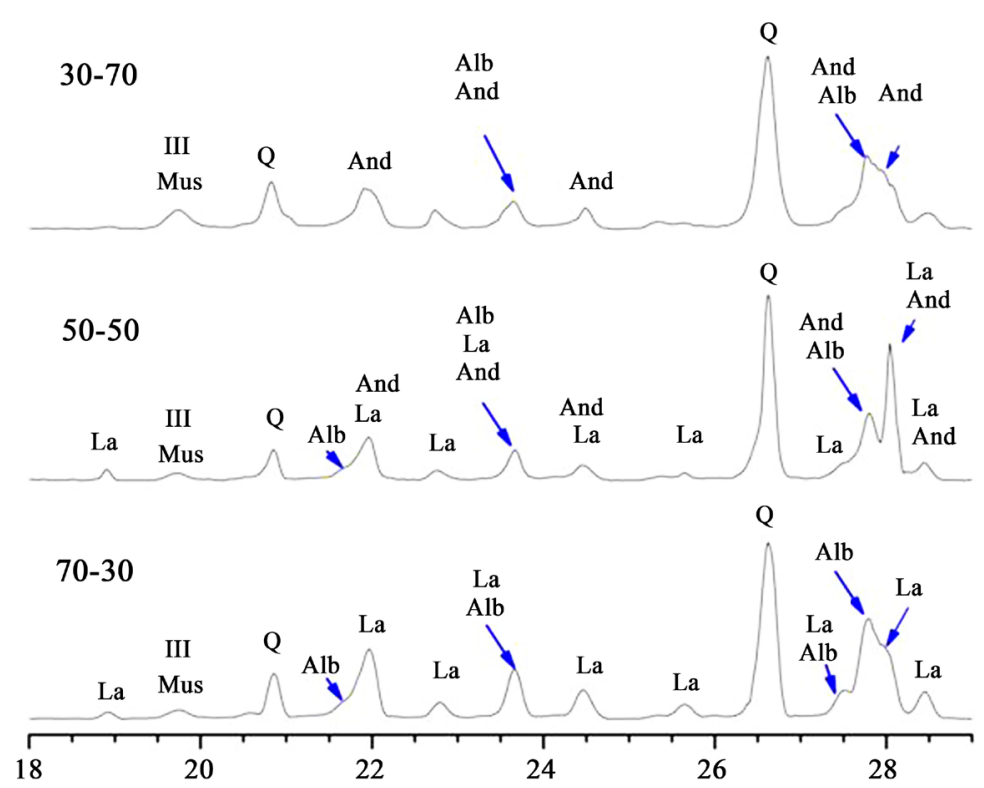

(b)

$2 \theta$

Figure 4. (a) Values of the optimization factor defined in Equation (10) for the various mixtures tested. (b) Diffractograms corresponding to samples with three different proportions of LVG and IND, sintered at $950^{\circ} \mathrm{C}$. Illite (Ill); muscovite-2M (Mus); kaolinite (k); anorthite (Anr), albite (Alb), labradorite (La), and andesine (And); and quartz (Q). 
different proportions of LVG and IND materials sintered at $950^{\circ} \mathrm{C}$, in which it can be observed that the evolution kinetics of the three mixtures are complex and distinct. The diffractogram of the sample with a proportion of 30 - 70 suggests a predominance of andesine, albite, and quartz, whereas in the diffractogram of the sample with a proportion of 50 - 50, a predominance of labradorite, andesine, and quartz is observed. Finally, the diffractogram of

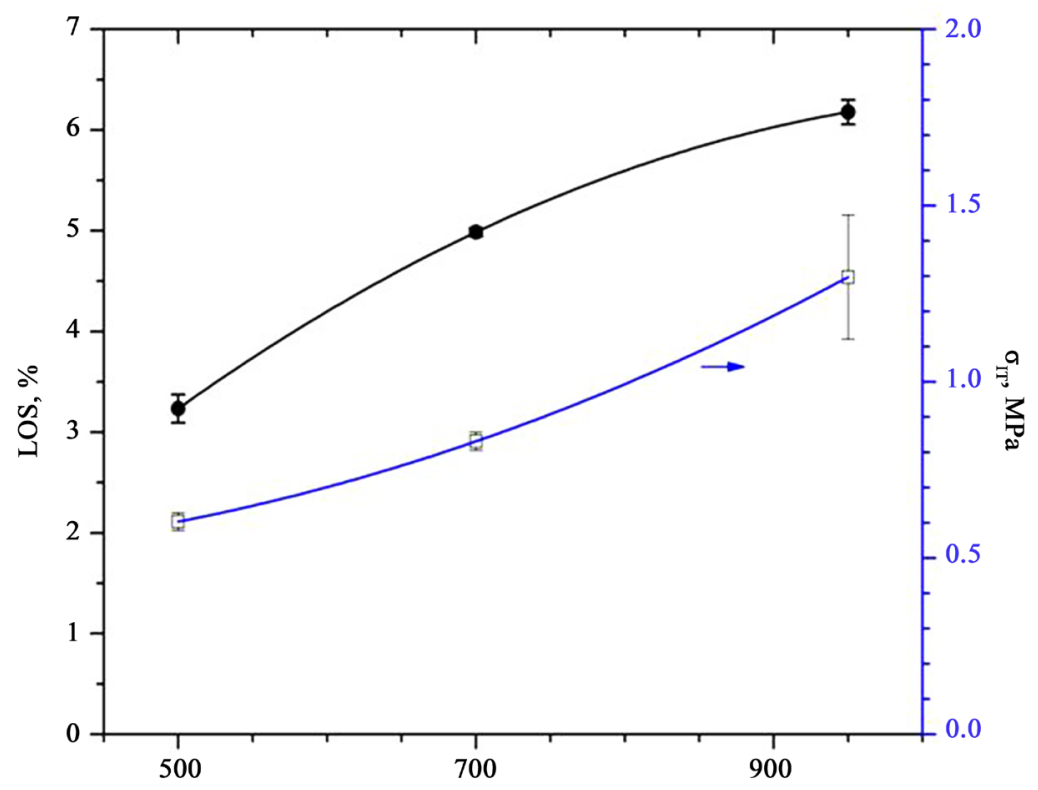

(a)

Temperature, ${ }^{\circ} \mathrm{C}$

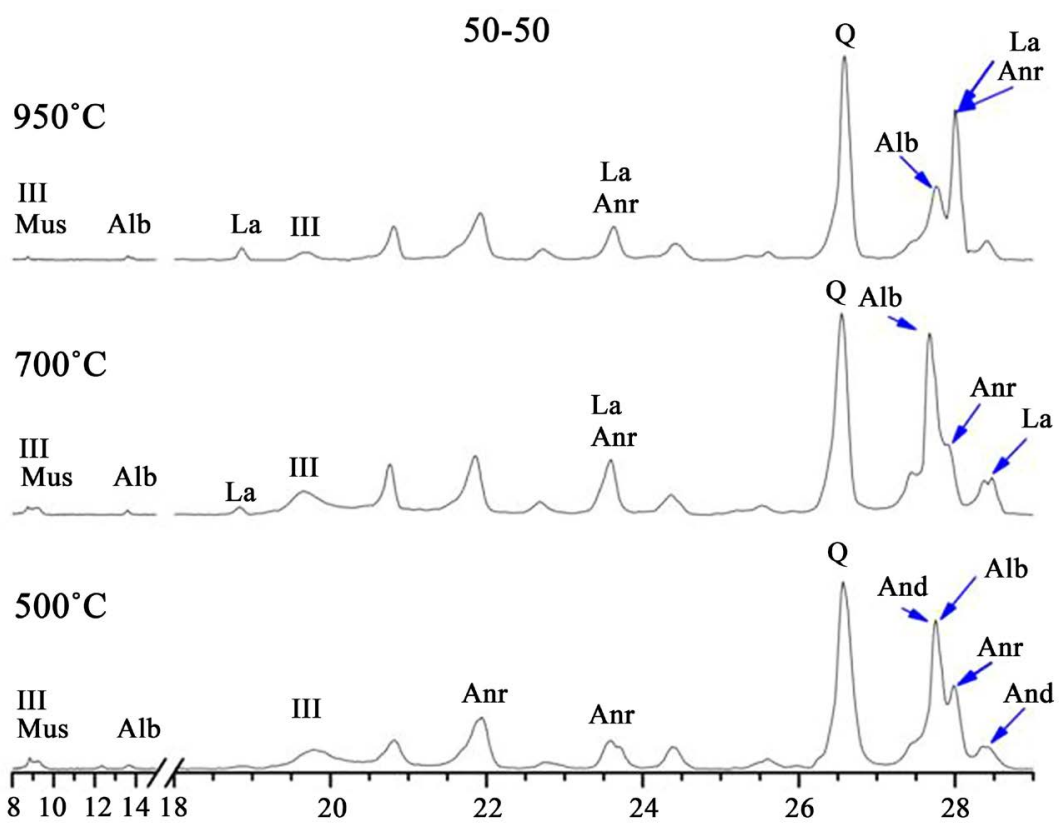

(b)

$2 \theta$

Figure 5. (a) Variation in the indirect tensile strength $\left(\sigma_{\mathrm{IT}}\right)$ of the $\mathrm{OM}$ as a function of the final sintering temperature. Also shown is the variation in the loss on sintering (LOS) as a function of the final sintering temperature. (b) Diffractograms of samples prepared using the $\mathrm{OM}$ and sintered at $500^{\circ} \mathrm{C}, 700^{\circ} \mathrm{C}$ and $950^{\circ} \mathrm{C}$. Illite (Ill); muscovite-2M (Mus); kaolinite (k); anorthite (Anr), albite (Alb), Labradorite (La), and andesine (And); and quartz (Q). 
the sample with a proportion of 70 - 30 indicates the presence of albite, labradorite, and quartz.

Figure 5(a) shows the variations in the indirect tensile strength and the loss on sintering for the OM as functions of the final sintering temperature. Figure 5(b) shows the diffractograms of samples prepared using the OM and sintered at $500^{\circ} \mathrm{C}, 700^{\circ} \mathrm{C}$ and $950^{\circ} \mathrm{C}$. For a sintering temperature of $500^{\circ} \mathrm{C}$, a predominance of andesine, albite, and anorthite is observed, whereas for $950^{\circ} \mathrm{C}$, there is a predominance of labradorite, anorthite, and albite. Thus, anorthite plays a very important role in the consolidation of the solid brick matrix because the decomposition of andesine into anorthite and albite contributes to the emergence of labradorite and the enrichment of the matrix with anorthite. As was mentioned, in one region of the andesine crystal, the APB recombines to form anorthite, whereas in another region of the same crystal, the structure transforms into albite without a superstructure [6] [7]. Smith and Brown 1988 reported that in an Anr-Alb- $\mathrm{SiO}_{2}-\mathrm{H}_{2} \mathrm{O}$ system, a viscous solution can be readily obtained as the temperature is increased, and it is detected when the quartz diffraction peak begins to disappear; in addition, the plagioclase chemical composition changes very slowly. This dissolution process occurs through a surface-controlled reaction [38]. It is also important to keep in mind that anorthite can be formed at a temperate of approximately $1000^{\circ} \mathrm{C}$ in a viscous solution of alumina, following the reaction:

$$
\mathrm{CaO}+\mathrm{Al}_{2} \mathrm{O}_{3}+\mathrm{SiO}_{2} \rightarrow \mathrm{CaAl}_{2} \mathrm{Si}_{2} \mathrm{O}_{8} \text { or } \mathrm{CaO}+\mathrm{Al}_{2} \mathrm{Si}_{2} \mathrm{O}_{7} \rightarrow \mathrm{CaAl}_{2} \mathrm{Si}_{2} \mathrm{O}_{8} \text {. }
$$

However, studies of the formation of anorthite crystalline nuclei and their effects on the increase in strength during sintering are rare in the literature [8] [39]. According to Abdrakhimova and Abdrakhimov, the addition of alkaline oxides to kaolinite and kaolinite-montmorillonite delays the crystallization of cristobalite and lowers the temperature at which the formation of mullite begins [40]. Meanwhile, the eutectic reaction between quartz and albite intensifies the formation of the vitreous phase at low sintering temperatures [41].

\subsection{Prognoses for Molding and/or Extrusion}

Figure 6(a) shows the mean granulometry of the LVG and IND materials as well as that of the OM. It also presents an evaluation of the potential uses of the OM in the fabrication of clay products. The IND sample was found to correspond to $8.63 \%$ gravel, $79.65 \%$ sand, and $11.71 \%$ silt plus clay, whereas the LVG sample exhibited a granulometry of $0 \%$ gravel, $3.55 \%$ sand, and $96.45 \%$ slit plus clay. The results for the OM indicated $0 \%$ gravel, $45.92 \%$ sand, and $54.08 \%$ silt plus clay. With this granulometry, and in accordance with the predictions performed with the aid of the diagram of granulometric domains, the OM has the potential for use in the fabrication of clay materials for the construction of hollow products. The characterization of the geotechnical properties of the OM reveals that the OM presented a behavior consistent with that of a low plasticity clay, similar to a sandy or silty clay (PI $=7 \%$; $L L=27 \%$ and PL $=20 \%$ ), whereas the LVG sample exhibited a behavior lying on the boundary between medium and high plasticity (PI $=27 \%$; $L L=50 \%$ and $\mathrm{PL}=17 \%$ ) (see Figure 6(b)).

Figure 6(c) presents the workability diagram [42]. In this figure, the prognoses for the molding and/or extrusion of the LVG and OM materials are illustrated in terms of Atterberg limits. From this diagram, it is apparent that the LVG sample exhibited plastic properties that are considered acceptable for molding, whereas the plastic properties of the $\mathrm{OM}$ are close to the boundary between acceptable molding and very plastic behavior, with low cohesion. The addition of "sandy" material up to a proportion of 50\% in the OM increases the fine sand content and results in a higher content of degreasing material and, consequently, lower plasticity.

\subsection{Strength and Durability}

Table 3 presents the characterization results for the bricks produced by seven regional artisans and for those fabricated in the laboratory using the OM. In general, clay bricks exhibit several properties that are important for the evaluation of their strength and durability. These properties are related to the quality of the raw material and are directly associated with the manufacturing conditions.

The baking and sintering of clay bricks produce a series of mineralogical, textural, and physical changes that depend on many factors that influence the porosity. The porosity is defined as the ratio of the empty volume in the specimen (pores and cracks) to its total volume. The porosity is an important parameter for clay bricks because of its influence on properties such as chemical reactivity, mechanical strength, durability, and general brick quality. The dimensions and distribution of the pores are influenced by the quality of the raw material, the presence of additives or impurities, the amount of water in the material, and the maximum sintering temperature. The total relative volume of pores that are in contact with the atmosphere, either directly or through other pores 


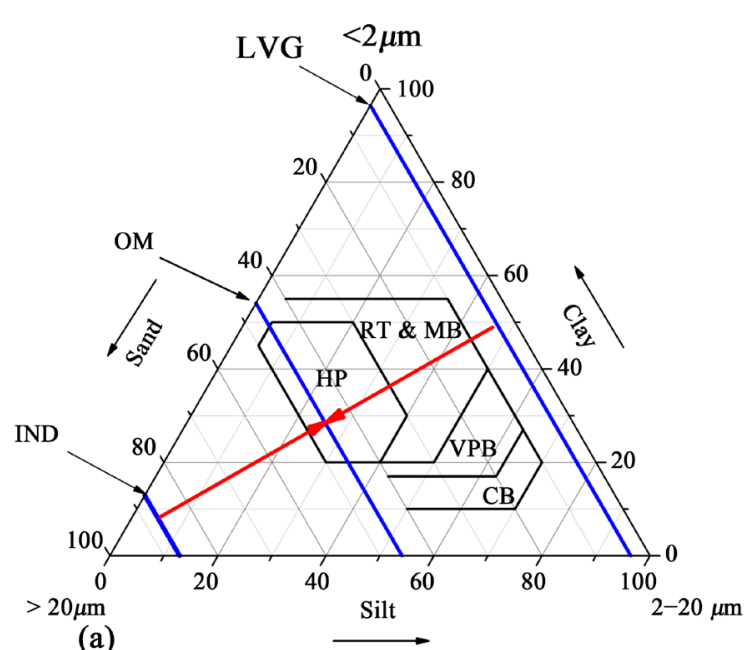

(a)

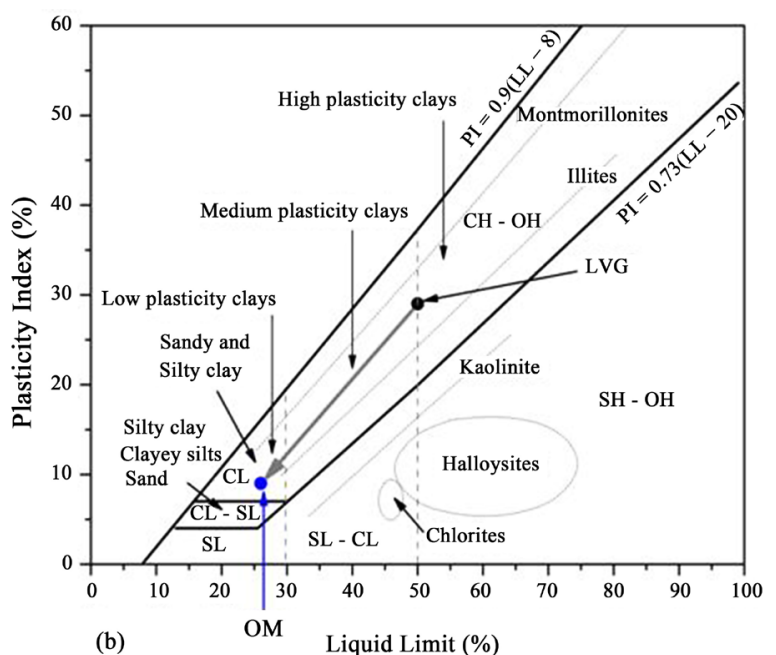

(b)

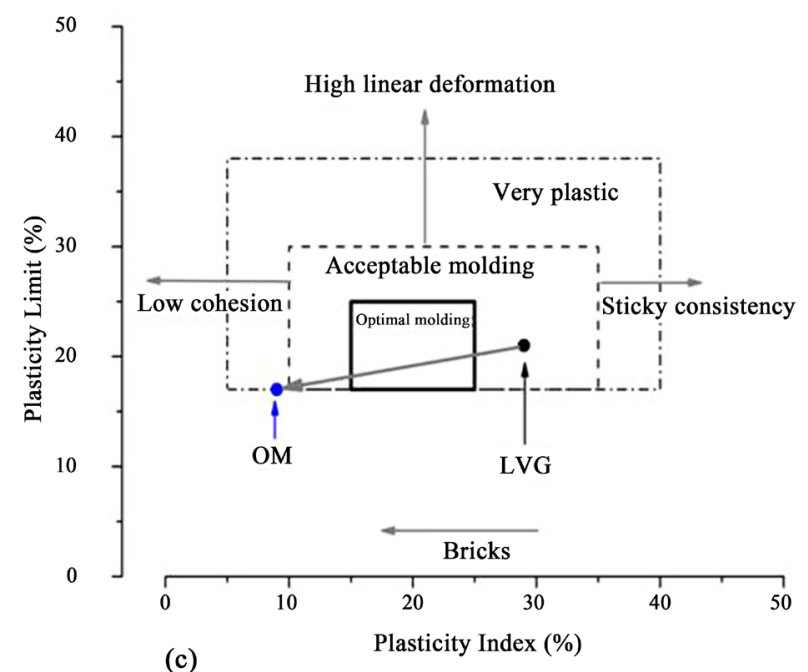

(c)

Figure 6. (a) Granulometry of the LVG, IND, and OM samples. The segments proceeding from the sand side to the silt side correspond to the sum of the slit and clay fractions. The segments with arrows point the OM granulometry. The spaces outlined inside the diagram represent the granulometric domains and their corresponding prognoses for use. Conventional brick (CB). Vertical perforated brick (VPB). Roofing tiles and masonry brick (RT \& MB). Hallow products (HP). (b) Geotechnical properties of the LVG and OM materials. The two letters used to indicate each subgroup are derived as combinations of the following letters: clay (C), silt (S), organic (O), high plasticity (H), and low plasticity (L). (c) Prognoses for molding and/or extrusion in terms of Atterberg limits.

(see Equation (5)), is represented by the fraction of open pores $\left(f_{0}\right)$ or the apparent porosity. The handmade bricks exhibited apparent porosities of between 25 and 34\%, whereas the bricks produced in the laboratory exhibited a value of only $21.93 \%$.

The apparent density describes the relationship between the weight of a dry brick and the volume occupied by the brick; thus, it serves as a measure of the proportion of matter that is present in that volume. From this description, it is evident that a higher value of this measure indicates a denser brick, with better mechanical properties and higher durability. Typical values of the apparent density $\left(\rho_{\mathrm{b}}\right)$ are between 1.20 and $1.90 \mathrm{~g} / \mathrm{cm}^{3}$. The apparent densities of the handmade bricks varied between 1.42 and $1.53 \mathrm{~g} / \mathrm{cm}^{3}$, whereas for the bricks produced in the laboratory, this value was $1.85 \mathrm{~g} / \mathrm{cm}^{3}$. The solid phase densities $\left(\rho_{\mathrm{s}}\right)$ of the handmade bricks varied between 2.02 and $2.27 \mathrm{~g} / \mathrm{cm}^{3}$, whereas the value for the bricks fabricated in the laboratory was $2.37 \mathrm{~g} / \mathrm{cm}^{3}$.

Pores constitute a large proportion of the volume of a brick, and when the brick is exposed to rain or washing, water penetrates into these pores. The water absorption behavior reflects the brick's water storage capacity and the ability of water to circulate inside the brick, the latter of which can promote deterioration and a reduction in 
Table 3. Characterization results for the bricks produced by seven regional producers and the bricks fabricated in the laboratory using the OM.

\begin{tabular}{lcccccccc}
\hline & P1 & P2 & P3 & P4 & P5 & P6 & P7 & Lab \\
\hline$W_{1}(\mathrm{~g})$ saturated in water & 2187 & 2371 & 2105 & 2071 & 2230 & 2342 & 2416 & 3305 \\
$W_{2}(\mathrm{~g})$ saturated in air & 5068 & 5277 & 4975 & 4785 & 5070 & 5115 & 5305 & 6388 \\
$W_{3}(\mathrm{~g})$ oven-dried & 4122 & 4459 & 4068 & 4094 & 4134 & 4243 & 4323 & 5712 \\
$W_{4}(\mathrm{~g})$ green & - & - & - & - & - & - & - & 6091 \\
$W A(\%)$ & 22.97 & 18.35 & 22.31 & 16.88 & 22.65 & 20.53 & 22.72 & 11.84 \\
$f_{o}(\%)$ open pores & 32.85 & 28.16 & 31.62 & 25.47 & 32.97 & 31.42 & 33.99 & 21.93 \\
$\rho_{\mathrm{b}}\left(\mathrm{g} / \mathrm{cm}^{3}\right)$ & 1.43 & 1.53 & 1.42 & 1.51 & 1.46 & 1.53 & 1.50 & 1.85 \\
$\rho_{\mathrm{s}}\left(\mathrm{g} / \mathrm{cm}^{3}\right)$ & 2.13 & 2.14 & 2.07 & 2.02 & 2.17 & 2.23 & 2.27 & 2.37 \\
$L O S(\%)$ & - & - & - & - & - & - & - & 6.64 \\
$\sigma_{c}(\mathrm{MPa})$ & 5.53 & 4.78 & 3.21 & 6.23 & 4.22 & 3.02 & 5.23 & 13.89 \\
Std. dev. of $\sigma_{C}$ & 0.63 & 0.27 & 0.71 & 0.47 & 1.16 & 0.43 & 1.05 & 0.54 \\
$f_{\text {opt }}(\mathrm{MPa} / \mathrm{kg})$ & 1.34 & 1.07 & 0.79 & 1.52 & 1.02 & 0.71 & 1.21 & 2.43 \\
\hline
\end{tabular}

$* W_{1}$ represents the weight of a saturated brick in water, $W_{2}$ represents the weight of a saturated brick in air, $W_{3}$ represents the weight of a brick after drying in an oven, and $W_{4}$ represents the weight of a green brick. WA represents the relative amount of adsorbed water. $f_{0}$ is the fraction of space occupied by open pores. $\rho_{\mathrm{b}}$ represents the apparent density, and $\rho_{\mathrm{s}}$ represents the density of the solid phase. LOS indicates the relative mass losses after baking and/or sintering. $\sigma_{\mathrm{C}}$ represents the compressive strength. Std.dev. of $\sigma_{\mathrm{C}}$ is the standard deviation of the compressive strength values. $f_{\mathrm{opt}}$ represents the optimization factor.

mechanical strength. At temperature below $0^{\circ} \mathrm{C}$, the water in the pores freezes, leading to delamination, disintegration, or "cracking". In the presence of soluble salts, the water tends to react with the brick, generating efflorescence. The increase in volume caused by the crystallization of salts can cause severe damage [43] [44]. In Table 3, it is reported that the water absorption (WA) in the handmade bricks varied between $16.88 \%$ and $22.97 \%$, whereas that in the bricks fabricated in the laboratory was only $11.84 \%$. The absorption remained below the limit established by the relevant standard; see ASTM standards [3]. However, the absorption of water is an important factor that affects brick durability. Lesser infiltration of water into a brick means that it remains harder and is more resilient to environmental damage. Therefore, the internal structure of a brick should be sufficiently compact to resist the intrusion of water. The nature of the pore network depends not only on the mass loss during baking and sintering but also on the proximity of the particles during the sintering process; closer particles result in a smaller pore size. In general, it is recommended for the water adsorption coefficient to be below $15 \%$ [44] [45].

The compressive strength of a brick provides a measure of its quality. The reported results represent the average values for tests performed on five samples. For the handmade bricks, values ranging from 3 to $5 \mathrm{MPa}$ were recorded, whereas the average value for the brick fabricated in the laboratory was $13.5 \mathrm{MPa}$; these findings suggest that the bricks fabricated in the laboratory using the OM exhibit a reasonably high compressive strength, corresponding to an improvement of $300 \%$ in this parameter. The compressive strength of a material is strongly influenced by the characteristics of the raw materials used and by the production process.

\section{Conclusions}

The optimization of the proportions of "clayey" and "sandy" materials used in handmade clay bricks has led to a substantial improvement (300\%) in their quality. This improvement should facilitate the more widespread use of these handmade bricks in the local construction industry of southern Ecuador. Clayey materials tend to form solid solutions during baking. The anorthite enrichment of these solid solutions that results from the evolution of andesine contributes to the formation of a stronger matrix among grains of different materials. This can be achieved by using "sandy" materials with high andesine content, which is a common feature of Ecuadorian soil.

The results of IT test performed on disk-shaped samples produced using different mixtures of "clayey" and 
"sandy" materials enabled the determination of the OM in terms of the value of the optimization factor defined in Equation (10). This is a suitable means of evaluation because the tensile strength primarily depends on the strengths of the mineral grains and of the matrix that binds them together. In addition, there is also a dependence on the chemical composition, the presence of inclusions, and the number and dimensions of the pores. Thus, the IT test has proven to be very sensitive to the strength of the brick binder matrix. The next natural step in this investigation will be to further improve the brick technology; to this end, we are studying the effects of organic additives such as sawdust, rice straw, and cane bagasse on the quality of bricks produced using the OM. It will be necessary to perform additional studies on the effect of anorthite on the increase in strength during sintering and on its behavior in the temperature range between $950^{\circ} \mathrm{C}$ and $1050^{\circ} \mathrm{C}$, in which we can expect to observe the early formation of mullite, among other phenomena.

\section{Acknowledgements}

The authors wish to express their gratitude to the Prometheus Project of the Secretary of Higher Education, Science, Technology and Innovation of the Republic of Ecuador (Proyecto Prometeo de la Secretaria Superior, Ciencia, Tecnología e Innovación de la República del Ecuador) and to the Technical University of Loja for the support provided during this investigation.

\section{References}

[1] Krakowiak, K.J., Lourenço, P.B. and Ulm, F.J. (2011) Multitechnique Investigation of Extruded Clay Brick Microstructure. Journal of the American Ceramic Society, 94, 3012-3022.

http://dx.doi.org/10.1111/j.1551-2916.2011.04484.x

[2] Monteiro, S.N. and Vieira, C.M.F. (2014) On the Production of Fired Clay Bricks from Waste Materials: A Critical Update. Construction and Building Materials, 68, 599-610. http://dx.doi.org/10.1016/j.conbuildmat.2014.07.006

[3] Zhang, L. (2013) Production of Bricks from Waste Materials-A Review. Construction and Building Materials, 47, 643-655. http://dx.doi.org/10.1016/j.conbuildmat.2013.05.043

[4] Mukherjee, S. and Ghosh, B. (2013) The Science of Clays: Applications in Industry, Engineering and Environment. Springer, Netherlands. http://dx.doi.org/10.1007/978-94-007-6683-9

[5] Arsenović, M., Pezo, L., Stanković, S. and Radojević, Z. (2015) Factor Space Differentiation of Brick Clays According to Mineral Content: Prediction of Final Brick Product Quality. Applied Clay Science, 115, 108-114. http://dx.doi.org/10.1016/j.clay.2015.07.030

[6] Wenk, H.R. and Nakajima, Y. (1980) Structure, Formation, and Decomposition of APB's in Calcic Plagioclase. Physics and Chemistry of Minerals, 6, 169-186. http://dx.doi.org/10.1007/BF00309854

[7] Wenk, H.R. (1979) An Albite-Anorthite Assemblage in Low-Grade Amphibolite Facies Rocks. American Mineralogist, 64, 1294.

[8] Abdrakhimov, V.Z. (2012) Effect of the Phase Composition on the Durability of Ceramic Facing of the Shakhi-Zinda Ensemble in Samarkand. Glass and Ceramics (English Translation of Steklo i Keramika), 69, 1-3. http://dx.doi.org/10.1007/s10717-012-9424-2

[9] ASTM D422-63(2007)e2 (2007) Standard Test Method for Particle-Size Analysis of Soils. ASTM International, West Conshohocken, PA.

[10] ASTM D4318-10e1 (2010) Standard Test Methods for Liquid Limit, Plastic Limit, and Plasticity Index of Soils. ASTM International, West Conshohocken, PA.

[11] ASTM C67-14 (2014) Standard Test Methods for Sampling and Testing Brick and Structural Clay Tile. ASTM International, West Conshohocken, PA.

[12] Velasco, P.M., Pilar, M., Ortiz, M., Antonio, M., Giró, M., Melia, D.M., et al. (2015) Development of Sustainable Fired Clay Bricks by Adding Kindling from Vine Shoot: Study of Thermal and Mechanical Properties. Applied Clay Science, 107, 156-164. http://dx.doi.org/10.1016/j.clay.2015.01.017

[13] Hall, C. and Hamilton, A. (2013) Porosity-Density Relations in Stone and Brick Materials. Materials and Structures, 48, 1265-1271. http://dx.doi.org/10.1617/s11527-013-0231-1

[14] Hangl, M., Borger, A., Danzer, R. and Luxner, H.M. (2002) Application of the Brazilian Disc Test for Strength Measurements on Ceramic Green Bodies. Fracture Mechanics of Ceramics, 13, 159-167. http://dx.doi.org/10.1007/978-1-4757-4019-6 12

[15] Hungerbühler, D., Steinmann, M., Winkler, W., Seward, D., Egüez, A., Peterson, D.E., et al. (2002) Neogene Strati- 
graphy and Andean Geodynamics of Southern Ecuador. Earth-Science Reviews, 57, 75-124. http://dx.doi.org/10.1016/S0012-8252(01)00071-X

[16] Gobierno Autónomo Descentralizado del Cantón Catamayo (2012) Unidad de Gobernabilidad y desarrollo Territorial. Plan de Desarrollo y Ordenamiento Territorial 2014-2022, 654.

[17] Kornilov, A.V. and Luzin, V.P. (2004) Effective Methods of Processing Argillaceous Materials for Building Ceramics. Glass and Ceramics, 61, 27-29. http://dx.doi.org/10.1023/B:GLAC.0000026767.89367.45

[18] Del Coz Díaz, J.J., García Nieto, P.J., Álvarez Rabanal, F.P. and Lozano Martínez-Luengas A. (2011) Design and Shape Optimization of a New Type of Hollow Concrete Masonry Block Using the Finite Element Method. Engineering Structures, 33, 1-9. http://dx.doi.org/10.1016/j.engstruct.2010.09.012

[19] Reed, J.S. (1995) Principles of Ceramics Processing. Wiley-Interscience Publication, Hoboken.

[20] Ramachandran, V.S., Paroli, R.M., Beaudoin, J.J. and Delgado, A.H. (2002) Handbook of Thermal Analysis of Construction Materials. William Andrew Publishing/Noyes, Norwich, 491-530.

[21] Arsenović, M., Pezo, L., Mančić, L. and Radojević, Z. (2014) Thermal and Mineralogical Characterization of Loess Heavy Clays for Potential Use in Brick Industry. Thermochimica Acta, 580, 38-45. http://dx.doi.org/10.1016/j.tca.2014.01.026

[22] Dweck, J. (2008) Qualitative and Quantitative Characterization of Brazilian Natural and Organophilic Clays by Thermal Analysis. Journal of Thermal Analysis and Calorimetry, 92, 129-135. http://dx.doi.org/10.1007/s10973-007-8751-y

[23] Brindley, W., Maroney, D.M. and Udagawa, S. (1961) High-Temperature Reactions of Clay Mineral Mixture and Their Ceramic Properties: III, Shrinkage and Porosity in Relation to Initial Mineralogy. Journal of the American Ceramic Society, 44, 42-47. http://dx.doi.org/10.1111/j.1151-2916.1961.tb15345.x

[24] Gualtieri, A.F. and Ferrari, S. (2006) Kinetics of Illite Dehydroxylation. Physics and Chemistry of Minerals, 33, 490501. http://dx.doi.org/10.1007/s00269-006-0092-z

[25] Chakraborty, A.K. (2014) Phase Transformation of Kaolinite Clay. Springer, New Delhi. http://dx.doi.org/10.1007/978-81-322-1154-9

[26] Brindley, G. (1961) Effect of Mineralogical Composition of Clays on the Properties of the Fired Body. Journal of the American Ceramic Society, 42-47.

[27] Gabor, M., Toth, M., Kristf, J. and Komaromi-hiller, G.I. (1995) Thermal Behavior and Decomposition of Intercalated Kaolinite. Clays and Clay Minerals, 43, 223-228. http://dx.doi.org/10.1346/CCMN.1995.0430209

[28] Ptáček, P., Šoukal, F., Opravil, T., Havlica, J. and Brandštetr, J. (2011) The Kinetic Analysis of the Thermal Decomposition of Kaolinite by DTG Technique. Powder Technology, 208, 20-25. http://dx.doi.org/10.1016/j.powtec.2010.11.035

[29] Gibbs, H.A.A., O’Garro, L.W. and Newton, A.M. (2000) Differential Thermal Analysis: A Means of Identifying Soil Samples from Barbados, Trinidad, Tobago, St. Vincent, Jamaica and Guyana. Thermochimica Acta, 363, 71-79. http://dx.doi.org/10.1016/S0040-6031(00)00628-6

[30] MacKenzie, R.C., Ed. (1972) Diferential Thermal Analysis. Academic Press, Lodon, 481-502.

[31] Araújo, J.H., De Silva, N.F., Acchar, W. and Gomes, U.U. (2004) Thermal Decomposition of Illite. Materials Research, 7, 359-361. http://dx.doi.org/10.1590/S1516-14392004000200024

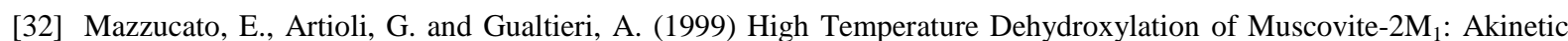
Study by in Situ XRPD. Physics and Chemistry of Minerals, 26, 375-381. http://dx.doi.org/10.1007/s002690050197

[33] Guggenheim, S. and Koster van Gross, A.F. (2001) Baseline Studies of the Clay Minerals Society Source Clays: Thermal Analysis. Clays and Clay Minerals, 49, 433-443. http://dx.doi.org/10.1346/CCMN.2001.0490509

[34] Frey, F., Jagodzinski, H., Prandl, W. and Yelon, W.B. (1977) Dynamic Character of the Primitive to Body-Centered Phase Transition in Anorthite. Physics and Chemistry of Minerals, 1, 227-231. http://dx.doi.org/10.1007/BF00307320

[35] Holm, J.L. and Kleppa, O.J. (1968) Thermodynamics of the Disordering Process in Albite. The American Mineralogist. 53, 123-133.

[36] Cradarelli, F. (2008) Materials Handbook: A Concise Desktop Reference. 2nd Edition, Springer, Berlin.

[37] Fernandes, F.M., Laurenco, P.B. and Castro, F. (2010) Ancient Clay Bricks: Manafacture and Properties. In: Bostenaru, D., Ed., Materials, Technologies and Practice in Historic Heritage Structures, Springer, Berlin, 29-48. http://dx.doi.org/10.1007/978-90-481-2684-2_3

[38] Smith, J.V. and Brown, W. (1988) Feldespar Minerals. Springer, Berlin. http://dx.doi.org/10.1007/978-3-642-72594-4

[39] Abdrakhimov, V.Z. and Abdrakhimova, E.S. (2015) Interrelation of the Phase Composition and Durability of More than 800 Year Old Brick for the Example of the Kazan Kremlin. Glass and Ceramics, 72, 71-75. 
http://dx.doi.org/10.1007/s10717-015-9727-1

[40] Abdrakhimova, E.S. and Abdrakhimov, V.Z. (1997) The Influence of Feldspar Concentrate on Phase Transformations in Ceramic Tile. Glass and Ceramics, 54, 326-329. http://dx.doi.org/10.1007/BF02765869

[41] Il'ina, P.V., Skamnitskaya, L.S. and Repnikova, E.A. (1999) Effect of Feldspar Concentrate Composition Mixtures on Structure and Properties of Ceramic. Glass and Ceramics, 56, 259-262. http://dx.doi.org/10.1007/BF02681508

[42] Bain, J.A. and Highley, D.E. (1979) Developments in Sedimentology. Proceedings of the 1978 VI International Clay Conference, Oxford, 10-14 July 1978, 437-446.

[43] Alonso-Santurde, R., Coz, A., Viguri, J.R. and Andrés, A. (2012) Recycling of Foundry By-Products in the Ceramic Industry: Green and Core Sand in Clay Bricks. Construction and Building Materials, 27, 97-106. http://dx.doi.org/10.1016/j.conbuildmat.2011.08.022

[44] Ajam, L., Ben Ouezdou, M., Felfoul, H.S. and Mensi, R.E. (2009) Characterization of the Tunisian Phosphogypsum and Its Valorization in Clay Bricks. Construction and Building Materials, 23, 3240-3247. http://dx.doi.org/10.1016/j.conbuildmat.2009.05.009

[45] Alviset, L. (1987) Matériaux de terre cuite. Techniques de l’ingénieur, C905, 1-20.

\section{Submit or recommend next manuscript to SCIRP and we will provide best service for you:}

Accepting pre-submission inquiries through Email, Facebook, LinkedIn, Twitter, etc.

A wide selection of journals (inclusive of 9 subjects, more than 200 journals)

Providing 24-hour high-quality service

User-friendly online submission system

Fair and swift peer-review system

Efficient typesetting and proofreading procedure

Display of the result of downloads and visits, as well as the number of cited articles

Maximum dissemination of your research work

Submit your manuscript at: http://papersubmission.scirp.org/ 